\title{
RANCANG BANGUN SISTEM MONITORING MUATAN BALON ATMOSFER PADA KOMPETISI MUATAN BALON ATMOSFER TAHUN 2019 LEMBAGA PENERBANGAN DAN ANTARIKSA NASIONAL (LAPAN) KABUPATEN GARUT
}

\author{
Putri Kartika Sari ${ }^{1}$, Afis Pratama ${ }^{2}$, Handini Arga Damar Rani ${ }^{3}$ \\ Universitas Ivet ${ }^{1,2,3}$ \\ Email: putrikartika@gmail.com
}

\begin{abstract}
ABSTRAK
Tujuan penelitian ini adalah membuat suatu rancangan sistem monitoring yang dapat digunakan untuk menampilkan dan menyimpan data profil vertikal atmosfer secara real time dan efisien bagi pengguna dengan memanfaatkan alat ukur yang dibangun dari beberapa sensor. Penelitian Research and Development (R\&D), dengan menggunakan metode pengembangan perangkat lunak Waterfall, yang meliputi: Communication, Planning, Modeling, Construction, dan Deployment. Sistem yang telah dirancang kemudian diuji dengan aspek usability. Subjek penelitian ini adalah pengamat parameter atmosfer atau juri utama KOMBAT 2019 yang berjumlah 3 orang, sekaligus sebagai responden pengujian usability. Hasil penelitian ini adalah (1). Sistem monitoring muatan balon atmosfer mampu mendeteksi suhu, kelembapan, tekanan udara, ketinggian dalam bentuk grafik, serta dapat mendeteksi arah angin, kecepatan angin dan juga letak lokasi dari koordinat lintang dan bujur. (2). Sistem monitoring ini telah melalui pengujian terhadap tingkat kualitas sistemnya pada aspek usability, yang memperoleh persentase sebesar $90 \%$ (sangat baik) dalam memonitoring muatan balon atmosfer.
\end{abstract}

Kata kunci: Sistem Monitoring, Muatan Balon Atmosfer, 3DR Radio Telemetry

\begin{abstract}
The purpose of this study is to create a monitoring system design that can be used to display and store atmospheric vertical profile data in real time and efficiently for users by utilizing measuring devices built from several sensors. Research and Development (R\&D), using the Waterfall software development method, which includes: Communication, Planning, Modeling, Construction, and Deployment. The system that has been designed is then tested with the usability aspect. The subjects of this study were observers of the parameters of the main KOMBAT 2019 atmosphere or judges, amounting to 3 people, as well as respondents testing usability. The results of this study are (1). Atmospheric balloon payload monitoring systems are able to detect temperature, humidity, barometric pressure, altitude in graphical form, and can detect wind direction, wind speed and location of latitude and longitude coordinates. (2). This monitoring system has undergone testing of the quality level of its system in the usability aspect, which obtained a percentage of $90 \%$ (very good) in monitoring atmospheric balloon loads.
\end{abstract}

Keywords: Monitoring System, Atmospheric Balloon Load, 3DR Radio Telemetry 


\section{PENDAHULUAN}

Seiring dengan perkembangan zaman dan teknologi kebutuhan informasi yang cepat sangat dibutuhkan dalam berbagai bidang, baik pertanian, perindustrian, maupun stasiun meteorologi sehingga bisa menunjang kinerja bidang tersebut. Salah satunya adalah informasi profil vertikal atmosfer. Informasi itu meliputi ketinggian, temperatur, kelembapan, tekanan, arah angin, kecepatan angin, lintang dan bujur.

Teknologi pengamatan atmosfer khususnya untuk pengamatan profil vertikal di Indonesia masih tergolong minim, sementara itu aktifitas atmosfer di daerah Indonesia sangat dinamis, sulit dipahami dan sulit untuk diprediksi. Saat ini teknologi pengamatan profil vertikal atmosfer masih mengandalkan produk dari luar negeri, sehingga perlu penguasaan teknologi pengamatan atmosfer secara mandiri.

Sebagai bagian dari program edukasi keantariksaan, Lembaga Penerbangan dan Antariksa Nasional (LAPAN) berupaya menyelenggarakan Kompetisi Muatan Balon Atmosfer (KOMBAT). Namun dalam pemantauan dan pengukuran tidak semua kondisi memungkinkan dilakukan secara langsung dikarenakan faktor geografis dan jarak, hal itu dapat menghambat memperoleh informasi tersebut. Kendala pengukuran pada lokasi yang sulit terjangkau dapat diatasi dengan menggunakan metode pengukuran jarak jauh (telemetri).

Oleh karena itu, dibutuhkan sebuah sistem yang mampu me-monitoring dan menyimpan data atau informasi profil vertikal atmosfer secara real time agar lebih mengefisienkan pengguna atau para antariksawan dalam memantau kondisi atmosfer sebelum mereka melakukan penelitiannya di angkasa. Sistem monitoring ini dapat bekerja dengan cara menerima data atau informasi profil vertikal atmosfer melalui alat-alat yang sudah dilengkapi sensor seperti, telemetri (antena) dan GPS sebagai TX (transmitter) dan RX (receiver) data, Arduino sebagai mikrokontroler sekaligus pengkonversi data analog ke digital, yang kemudian data itu akan diterima dan disimpan pada database sistem yang telah dibuat.

Maka penulis tertarik untuk mengangkat permasalahan tersebut sebagai proyek skripsi dengan judul "Rancang Bangun Sistem Monitoring Muatan Balon Atmosfer Pada KOMBAT 2019".

Berdasarkan uraian diatas, maka dapat dirumuskan permasalahan yang ada yaitu sebagai berikut: (1) Bagaimana cara membuat sistem monitoring profil vertikal atmosfer secara real time?, (2) Bagaimana cara menyimpan, menyajikan dan menampilkan data profil vertikal atmosfer yang efisien bagi pengguna?

Tujuan dari penelitian ini adalah membuat suatu rancangan sistem monitoring yang dapat digunakan untuk menampilkan dan menyimpan data profil vertikal atmosfer secara real time dan efisien bagi pengguna dengan memanfaatkan alat ukur yang dibangun dari beberapa sensor.

Manfaat yang diharapkan dari penelitian ini adalah sebagai berikut: (1) Bagi Penulis: Mampu mengaplikasikan ilmu yang didapat pada waktu kuliah dalam merancang sistem monitoring muatan balon atmosfer pada KOMBAT

2019. (2) Bagi Pengguna: Dapat memberikan kemudahan dalam memperoleh data atau informasi mengenai profil vertikal atmosfer secara real time. (3) Bagi Universitas IVET: Dapat digunakan sebagai arsip kampus dan referensi penelitian pengembangan yang serupa.

\section{TINJAUAN PUSTAKA}

\section{High Altitude Balloon}

High Altitude Ballon (HAB) adalah sebuah balon besar tak berawak biasanya terisi dengan helium atau hidrogen yang dilepaskan ke stratosfer. Balon ini mampu membawa sekelompok objek hingga ketinggian 100.000 feet dari permukaan 
bumi. Objek yang biasa dibawa oleh HAB disebut payload.

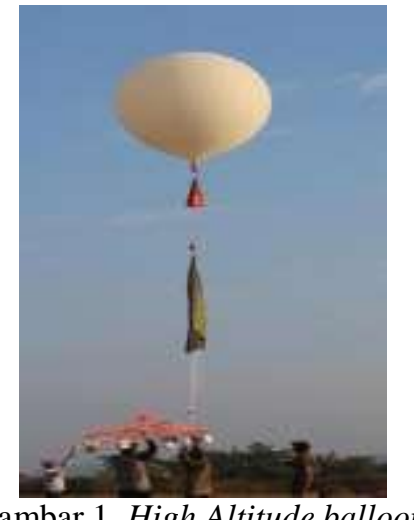

(Sumber:https://en.m.wikipedia.org/wiki/Highaltitude ballon)

HAB ini mengagumkan karena memungkinkan akses cepat dalam mengetahui kondisi cuaca dan parameter atmosfer dengan cepat.

\section{Payload}

Isi muatan balon atmosfer (payload) merupakan sebuah benda yang berisi sensor-sensor, telemetri dan mikrokontroller yang akan diterbangkan dengan wahana balon atmosfer. Muatan balon atmosfer dapat mengukur parameterparameter atmosfer vertikal dan mengirimkan datanya melalui radio telemetry kepada sistem penerima di permukaan bumi. Payload juga dapat diartikan sebagai nano satelit (Koko Himawan Permadi, 2013).

Berikut penjelasan komponen elektronika pada payload dalam penelitian ini, meliputi:

\section{Mikrokontroller}

Suatu alat elektronika digital yang mempunyai masukan dan keluaran serta kendali dengan program yang bisa ditulis dan dihapus dengan cara khusus, cara kerja mikrokontroller sebenarnya membaca dan menulis data (Muhammad Syahwil, 2013).

Di dalam skripsi ini, penulis menggunakan sebuah mikrokontroller Arduino. Arduino Mega 2560 adalah papan pengembangan mikrokontroller yang berbasis Arduino dengan menggunakan chip ATmega2560. Board

ini memiliki pin I/O yang cukup banyak, sejumlah 54 buah digital $\mathrm{I} / \mathrm{O}$ pin (15 pin diantaranya adalah $P W M), 16$ pin analog input, 4 pin UART (serial port hardware). Arduino Mega 2560 dilengkapi dengan sebuah oscillator $16 \mathrm{Mhz}$, sebuah port USB, power jack DC, ICSP header, dan tombol reset. Board ini sudah sangat lengkap, sudah memiliki segala sesuatu yang dibutuhkan untuk sebuah mikrokontroller.

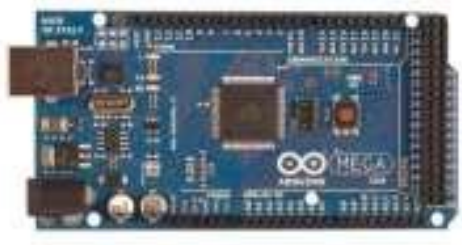

Gambar 2. Arduino Mega 2560

(Sumber: ArduinoMega2560Datasheet.pdf)

\section{Telemetry 3DR $433 \mathrm{MHz}$}

Radio telemetri adalah sebuah perangkat komunikasi yang menggunakan gelombang radio untuk mengirimkan sebuah informasi dengan jarak jauh (sumber:

http://ardupilot.org/copter/docs/commontelemetry-landingpage.html). Pada penelitian muatan balon atmosfer ini menggunakan telemetri 3DR $433 \mathrm{MHz}$. 3DR Radio telemetri adalah modem radio jarak menengah. Radio ini memiliki dua tipe berdasarkan frekuensi yaitu $915 \mathrm{MHz}$ dan $433 \mathrm{MHz}$ yang mempunyai kisaran jarak 1 mil. Terdapat dua modul yaitu transmitter (TX) dan receiver ( $\mathrm{RX})$. Alat bekerja pada catu daya $5 \mathrm{~V}$, dengan menggunakan 3DR Radio Config alat dapat diatur berdasarkan kebutuhan pemakai, seperti merubah baud rate, air speed, TX power.

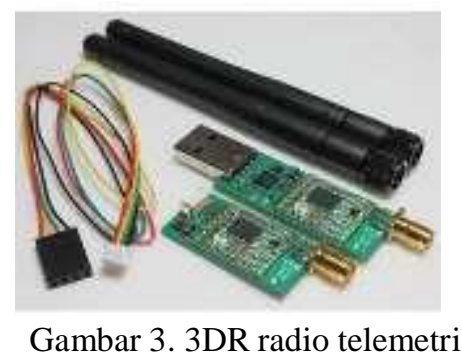




\section{Sensor GPS}

Pada penelitian kali ini, penulis menggunakan modul GPS uBlox Neo-7m. GPS uBlox Neo-7m ini adalah keluaran terbaru dan diatas dari Neo-6m yang dimana lebih memiliki kecepatan membaca ke satelit lebih cepat. Sensitivitas Neo-7m membaca lebih cepat karena GPS ini memiliki fitur warm start. Warm start adalah suatu keadaan dimana pada saat sensor GPS direstart, GPS tidak perlu mengulang dari awal untuk mengunci satelit.

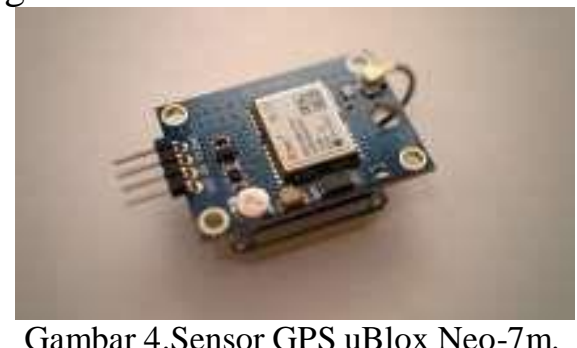

\section{Sensor BME280}

Sensor kelembaban memiliki waktu respons yang sangat cepat yang mendukung persyaratan kinerja untuk aplikasi yang muncul seperti kesadaran konteks, dan akurasi tinggi pada rentang suhu yang luas. Sensor tekanan adalah sensor tekanan barometrik absolut dengan fitur akurasi dan resolusi sangat tinggi pada noise yang sangat rendah. Sensor suhu terintegrasi telah dioptimalkan untuk noise yang sangat rendah dan resolusi tinggi. Ini terutama digunakan untuk kompensasi suhu dari sensor tekanan dan kelembaban, dan juga dapat digunakan untuk memperkirakan suhu sekitar (sumber:https://www.bosch-

sensortec.com/bst/products/all_products/b $\underline{\text { me280). }}$.

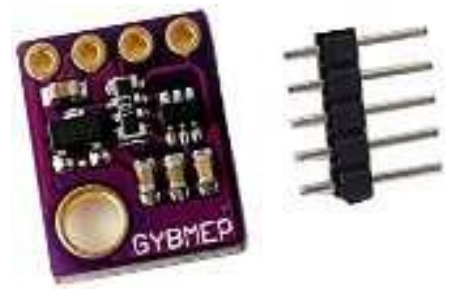

Gambar 5. Sensor BME280

\section{Sistem Monitoring}

Sistem adalah sekelompok unsur yang erat hubungannya satu dengan yang lain, yang berfungsi bersama-sama untuk mencapai tujuan tertentu (Sutabri, 2012:

6). Monitoring didefinisikan sebagai siklus kegiatan yang mencakup pengumpulan, peninjauan ulang, pelaporan, dan tindakan atas informasi suatu proses yang sedang diimplementasikan (Mercy, 2005).

Berdasarkan uraian diatas mengenai sistem dan monitoring, maka dapat diambil kesimpulan bahwa sistem monitoring adalah kumpulan siklus kegiatan yang mencakup pengumpulan, pelaporan dan tindakan atas informasi suatu proses yang sedang diimplementasikan.

\section{GUI (Graphical User Interface)}

Graphical User Interface (GUI) adalah bagian penting dari setiap aplikasi perangkat lunak bagi pengguna pada saat ini dan GUI juga harus memenuhi kriteria berikut : significant design, development, dan testing activities (Zafar Singhera, Ellis Horowitz dan Abad Shah, 2009). Dalam hal ini dengan memanfaatkan GUI (Graphical User Interface) program akan jauh lebih menarik. Selain itu program akan memiliki tampilan lebih efektif dan interaktif (Kamsyakawuni, 2010:35).

\section{Visual Studio 2019}

\section{Integrated}

Development

Environment (IDE) Visual Studio adalah landasan peluncuran kreatif yang dapat digunakan untuk mengedit, men-debug, dan membuat kode, lalu menerbitkan aplikasi. Pada penelitian sistem monitoring ini, penulis menggunakan Visual Studio versi terbaru yaitu Visual Studio 2019 versi 16.2.dengan versi NET Framework 4.8. Dengan Visual Studio 2019 ini, akan mendapatkan tools dan layanan terbaik, di kelasnya untuk pengembangan apapun, aplikasi apapun, dan platform apapun. Visual Studio 2019 tersedia untuk Windows dan Mac. Disini penulis berfokus pada peggunaan Visual Studio 
2019 dengan versi Windows (Sumber: http://docs.microsoft.com/enus/visualstudio/get-started/visual-studioide?view=vs-2019).

\section{METODE PENELITIAN}

Model penelitian yang digunakan dalam penelitian ini adalah pendekatan metode Research and Development (R\&D). R\&D yaitu kegiatan penelitian yang digunakan untuk menghasilkan produk dan menguji keefektifan dari produk yang dibuat (Sugiyono 2015, 407). Metode pengembangan yang digunakan adalah model waterfall dari Roger S. Pressman.

\section{Prosedur Pengembangan}

Menurut (Pressman, 2015:42), model waterfall adalah model klasik yang bersifat sistematis, berurutan dalam membangun software. Fase-fase dalam Waterfall Model menurut referensi Pressman:

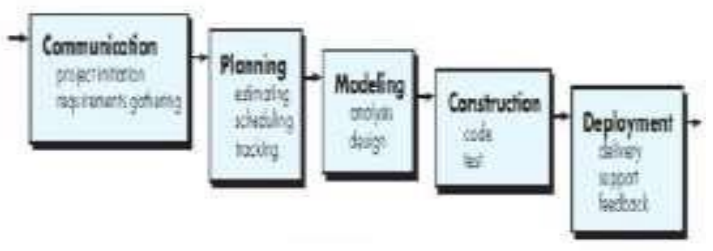

Gambar 6. Waterfall Pressman (Pressman, 2015: 42)

\section{Perancangan Perangkat Lunak}

Pada bagian perancangan perangkat lunak diawali dengan pembuatan flowchart terlebih dahulu.

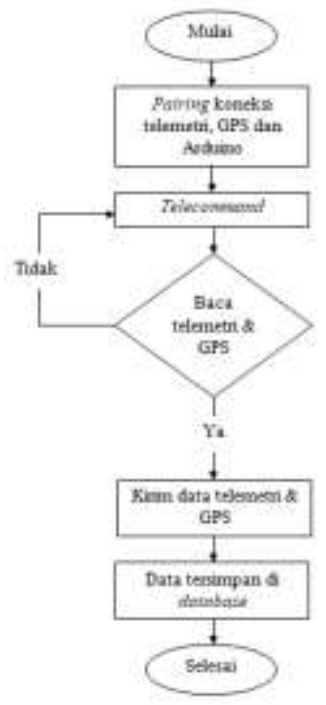

Gambar 7. Flowchart sistem monitoring

Berdasarkan gambar diatas dijelaskan bahwa alur perangkat lunak sistem monitoring pada muatan balon atmosfer dimulai dari pemasangan koneksi telemetri TX, GPS dan Arduino. Setelah komponen elektronikanya terkoneksi, lalu terjadi proses telekomunikasi antar telemetri dan GPS, jika data bisa terbaca maka akan terjadi proses penerimaan data, yang kemudian data itu akan tersimpan di dalam database sistem.

\section{Perancangan Perangkat Keras}

Pada tahapan ini dilakukan perancangan diagram blok dari cara kerja keseluruhan sistem.

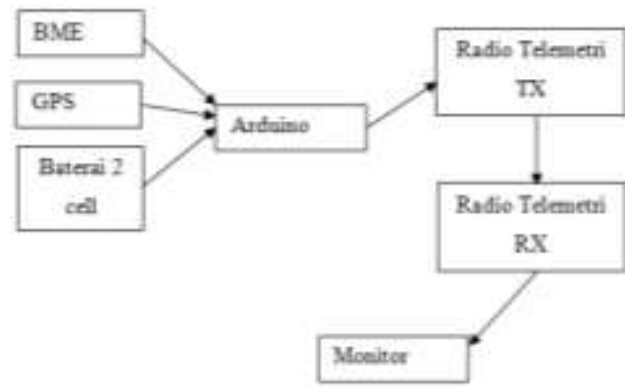

Gambar 8. Diagram Blok Sistem

Berdasarkan gambar di atas cara kerja perangkat keras diawali dari pengiriman data dari sensor BME, GPS, ke Arduino. Kemudian data dari Arduino dikirim radio telemetry TX dengan daya listrik dari Baterai 2 cell. Kemudian tersedia monitor untuk menampilkan 
sistem monitoring pada muatan balon atmosfer yang dipasang USB dengan menerima data dari radio telemetri $\mathrm{RX}$ yang sudah terkoneksi dengan telemetry TX.

\section{Perancangan Wiring Diagram}

Pada bagian perancangan wiring diagram ini berfungsi untuk mempermudah saat merangkai komponen elektronika yang dibutuhkan. Perancangan komponen menggunakan software Fritzing.

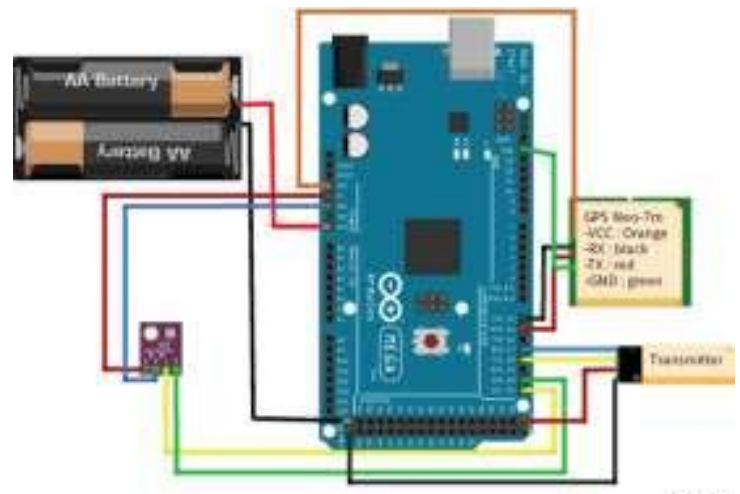

Gambar 9.Wiring Diagram

Sistem monitoing muatan balon atmosfer ini menggunakan microcontroler Arduino Mega 2560 sebagai pengolah data input dari sensor sehingga dapat menghasilkan output yang diinginkan. Sensor yang digunakan yaitu sensor BME280 dan GPS Neo-7m. Sensor BME280 digunakan untuk mengukur temperatur, kelembapan dan tekanan pada muatan balon atmosfer. Output sensor BME280 ini dihubungkan dari pin VCC ke pin 5V, Gnd ke Gnd, SCL ke pin SCL, dan SDA ke pin SDA. Sensor GPS Neo-7m digunakan untuk mengukur lintang, bujur, dan ketinggian. Output GPS ini dihubungkan dari pin VCC ke pin 3,3V, Tx ke Rx, dan Gnd ke Gnd. Pada sistem ini terdapat telemetri 3DR $433 \mathrm{MHz}$ yang digunakan sebagai Transmitter untuk dapat mengirim data ke telemetri Receiver yang terpasang dengan monitor.

\section{User Interface (Desain Antarmuka)}

Pada tahapan ini perancangan desain antarmuka dari sistem monitoring pada muatan balon atmosfer dengan menggunakan Balsamiq Mockup.

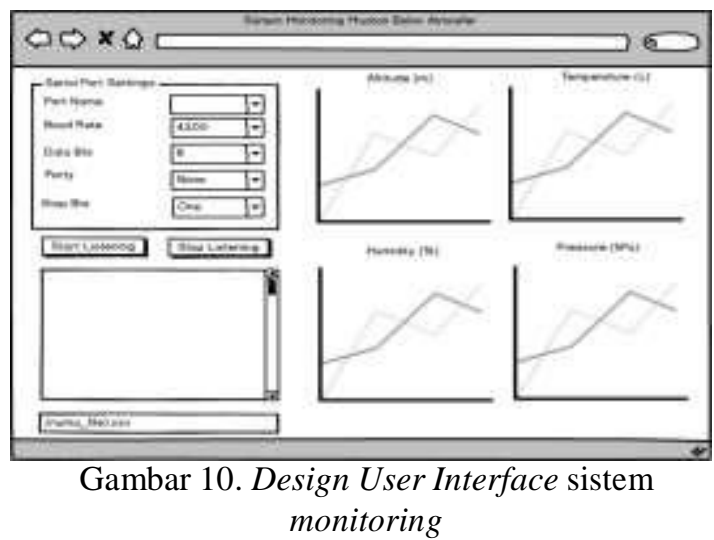

Sumber Data atau Subjek Penelitian

Sumber data dalam penelitian ini terdiri dari beberapa responden untuk pengujian perangkat lunak dan perangkat keras. Sugiyono (2015: 118) mengemukakan bahwa sampel adalah bagian dari jumlah dan karakteristik yang dimiliki oleh populasi. Pada penelitian ini pengambilan sample menggunakan teknik sampling jenuh.

Subjek penelitian aspek usability adalah 3 orang validator, yaitu Dr. Didi Satiadi, M.Sc., Dr. Laras Tursilowati, M.Si., dan Dr. Asif Awaludin, M.T. selaku juri utama dari lomba KOMBAT 2019.

\section{Metode Pengumpulan Data}

Dalam melakukan penelitian ini menggunakan beberapa metode pengumpulan data, antara lain: (1) Observasi: Observasi dilakukan dengan cara mengamati secara langsung sistem monitoring pada muatan balon atmosfer yang sudah ada sebelumnya dan dari hasil observasi ini dapat diperoleh gambaran fitur-fitur apa saja yang harus ada dalam sistem yang akan dibuat agar sistem monitoring ini dapat berfungsi lebih baik. (2) Kuesioner: Kuesioner merupakan cara mengumpulkan data secara tidak langsung. Kuesioner berupa pertanyaan yang diberikan kepada responden. Hal ini dimaksudkan untuk mengetahui respon user terhadap aspek usability pada perangkat lunak yang akan dikembangkan. 


\section{Instrumen Penelitian}

Instrumen penelitian yang digunakan untuk menguji kualitas perangkat lunak dan perangkat keras ini yaitu menggunakan instrumen usability ISO 9126.

\section{Usability}

Instrumen yang digunakan dalam pengujian usability menggunakan kuesioner USE Quistionnaire dari Arnold M.Lund. USE Quistionnaire mempunyai 4 aspek yaitu usefullness (kegunaan), satisfaction (kepuasan), ease of use (mudah digunakan) dan ease of learning (mudah dimengerti). Menurut Sauro (2010) apabila kuesioner yang digunakan mempunyai pertanyaan yang banyak, maka disarankan menggunakan skala Likert. Skala Likert dengan skala 5 sering digunakan peneliti untuk mengukur tingkat kesuksesan dalam penelitian (Losby and Wetmore, 2012). Skala tersebut meliputi: sangat setuju (SS), setuju (S), ragu-ragu (RG), tidak setuju (TS), sangat tidak setuju (STS).

\section{Analisis Data Aspek Usability}

Untuk keperluan analisis maka selanjutnya jawaban yang tersedia pada skala Likert dapat diberi skor (Sudaryono, 2015:62), sebagai berikut:

(a) Sangat Setuju (SS) $=5$,

(b) Setuju (S) = 4,

(c) Ragu-Ragu $(\mathrm{RG})=3$,

(d) Tidak Setuju (TS) $=2$,

(e) Sangat Tidak Setuju (STS) $=1$.

Jumlah nilai yang diperoleh selanjutnya diakumulasikan dan dihitung menggunakan rumus dibawah ini:

Keterangan:

Skor Total = Nilai total yang didapat dari jawaban responden

Skor Maksimal = Jumlah pernyataan $\mathrm{x}$ jumlah responden $\mathrm{x} 5$
Setelah didapatkan hasil presentase pencapaian dari perhitungan sebelumnya, selanjutnya hasil tersebut dikonversi menjadi nilai berskala 5 dengan skala Likert. Hasil konversi presentase ke pernyataan seperti dalam Tabel 1 .

Tabel 1. Tabel Kriteria Interprestasi Skor

\begin{tabular}{|c|c|c|}
\hline No $_{0}$ & Persentase Pencapaian & Interprestasi \\
\hline 1 & $0 \%-19,99 \%$ & Sangat Tidak Baik \\
\hline 2 & $20 \%-39,99 \%$ & Kurang Baik \\
\hline 3 & $40 \%-59,99 \%$ & Cukup Baik \\
\hline 4 & $60 \%-79,99 \%$ & Baik \\
\hline 5 & $80 \%-100 \%$ & Sangat Baik \\
\hline
\end{tabular}

\section{HASIL DAN PEMBAHASAN} Analisis Kebutuhan Fungsional

Kebutuhan fungsi atau fitur yang ada pada sistem monitoring muatan balon atmosfer berdasarkan analisis yang telah dilakukan adalah sebagai berikut:

a. Sistem memiliki satu jenis user.

b. Sistem hanya dapat diakses jika user telah melakukan konektivitas antara telemetri receiver yang berada pada PC dengan telemetri transmitter yang berada di payload.

c. Pengguna dapat melihat alur grafik parameter atmosfer, mengetahui tata letak geografis payload melalui maps GPS yang ada di sistem, dan menyimpan data monitoring atmosfer dalam format .csv dan .txt.

d. Pengguna dapat menyimpan hasil grafik parameter atmosfer dalam format .jpg.

\section{Analisis Kebutuhan Hardware}

Kebutuhan hardware atau perangkat keras dalam rancang bangun sistem monitoring ini antara lain:
a. PC/laptop
b. Arduino MEGA 2560
c. Sensor BMP/E 280
d. Sensor GPS NEO 7M e.
3DR Radio Telemetry f.
Baterai UltraFire 2 cell
g. Kabel Jumper Male-Female
h. Kabel USB type A to USB type B 


\section{Analisis Kebutuhan Software}

Kebutuhan software atau perangkat lunak dalam rancang bangun sistem monitoring ini antara lain:

a. Sistem Operasi Windows 10 .

b. Software Microsoft Visual Studio 2019 versi 16.2.3 untuk perancangan dan pengkodean sistem monitoringmuatan balon atmosfer.

c. Balsamiq Mockups 3 untuk desain sistemmonitoring.

d. Software Fritzing untuk desain wiring diagram.

e. Software Arduino IDE versi 1.8.7 untuk pengkodean arduino dan sensorsensor yang digunakan.

f. Software AccessPort versi 1.37 untuk komunikasi port serial dasar dan konfigurasi perangkat RS232/serial.

g. Software SikRadio Config versi 1.4 untuk konfigurasi radio 3DR.

\section{Pengujian Sistem Monitong Muatan Balon Atmosfer}

Pengujian dari proses ini bertujuan untuk mengetahui sistem monitoring yang telah di rancang dapat menerima data/informasi profil vertikal atmosfer yang dikirim melalui payload yang telah diterbangkan ke angkasa.

Peralatan yang dibutuhkan untuk pengujian sistem adalah sebagai berikut:

a. Laptop/PC dengan spesifikasi laptop yang digunakan penulis antara lain:

- Laptop Asus A455L 14"

- Operating System Windows 10 Enterprise 64-bit

- RAM 6 GB

- Processor Intel(R) Core(TM) i34030U CPU@1.90GHz

b. Rancangan payload yang telah siap diterbangkan ke angkasa menggunakan High Altitude Ballon (HAB).

c. 3DR Radio Telemetry yang digunakan sebagai receiver datanya ke sistem monitoring.

Langkah-langkah yang dilakukan untuk melakukan pengujian software adalah sebagai berikut:
(1) Pertama mempersiapkan rangkaian payload untuk diterbangkan dengan menggunakan balon besar berisi hellium seperti pada gambar berikut:

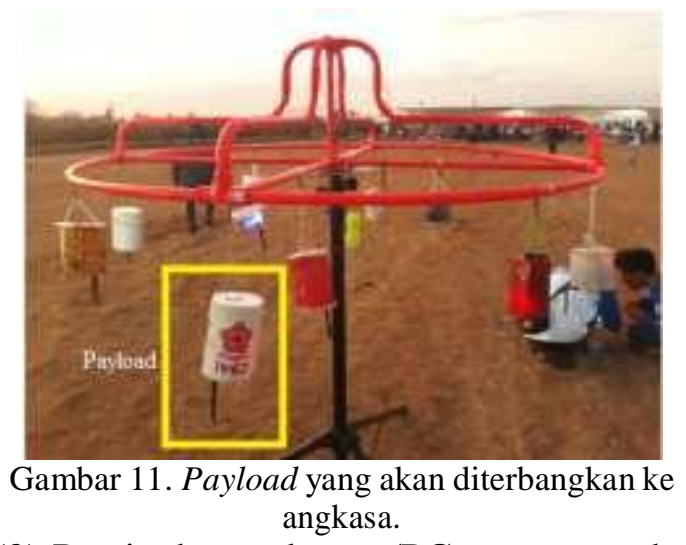

(2) Persiapkan laptop/PC yang akan digunakan untuk menampilkan sistem monitoring yang telah dibuat.

(3) Bukatampilan sistem monitoring-nya, disini penulis menggunakan Visual Studio 2019 untuk merancang sistemnya. Cara membuka filenya yaitu klik folder yang digunakan untuk menyimpan sistemnya - klik $2 \mathrm{x}$ folder bin- klik 2x folder Debug - klik $2 \mathrm{x}$ (nama file visual studio).exe, maka akan tampil seperti berikut:

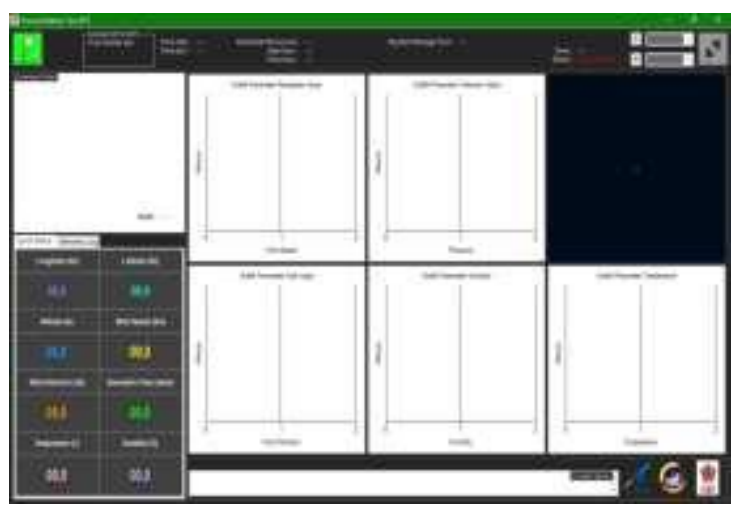

Gambar 12. Tampilan awal Sistem Monitoring muatan balon atmosfer

(4) Hubungkan 3DR Radio Telemetry USB ke laptop/PC yang digunakan. Kemudian sesuaikan port telemetry ke sistem monitoring dengan cara 
membuka device manager, seperti gambar berikut:

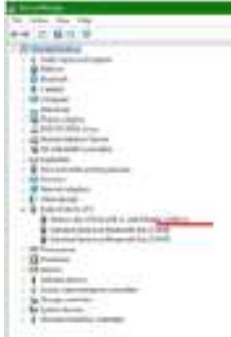

Gambar 13. Tampilan device manager dengan port COM12

(5) Setelah disesuaikan Port COM dan Baudrate nya maka klik icon Connectyang ada di pojok kanan atas pada sistem monitoringnya.

\section{Hasil Pengujian Sistem Monitoring Muatan Balon Atmosfer}

Berdasarkan hasil pengujian dari berbagai sensor dan telemetry yang tidak mengalami error, maka sistem monitoring muatan balon atmosfer akan menampilkan data yang diterima sebagai berikut:

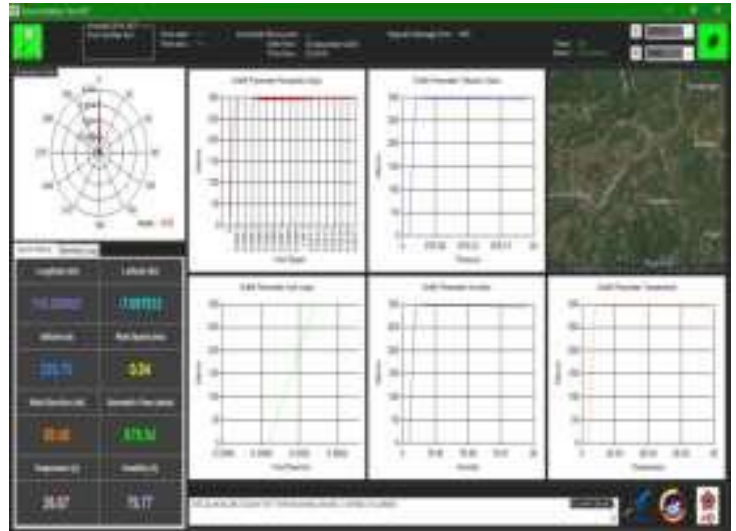

Gambar 14. Sistem Monitoring Muatan Balon Atmosfer

Tabel 2. Data Hasil Pengujian Sistem Monitoring

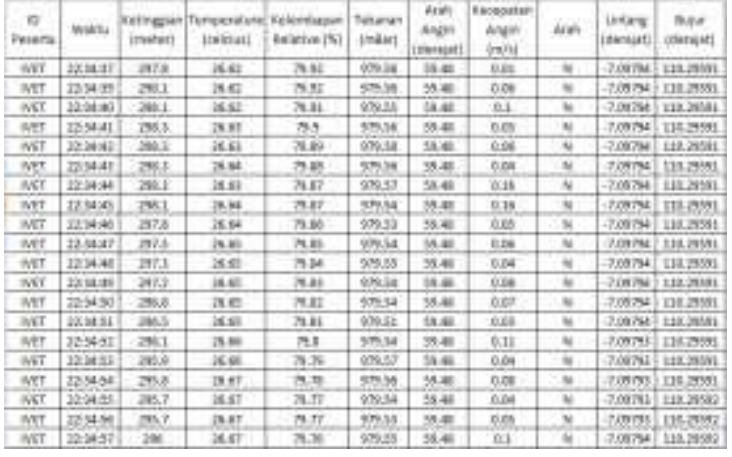

Pada hasil pengujian sistem monitoring muatan balon atmosfer ini juga dapat menyimpan grafik parameter dan arah payloaddengan format .jpg, seperti gambar berikut:

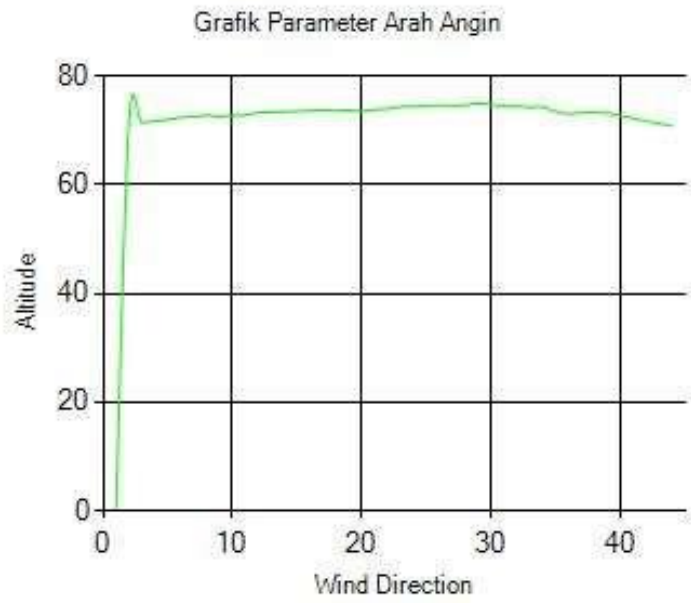

Gambar 15. Grafik Parameter pada Sitem Monitoring

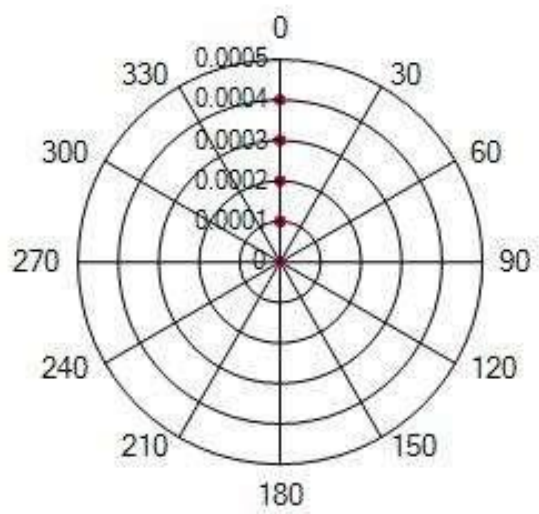

Gambar 16. Arah Payload berada.

\section{Hasil Pengujian Aspek Usability}

Pada pengujian aspek usability peneliti menggunakan 3 (tiga) orang responden yang merupakan juri utama pada Kompetisi Muatan Balon Atmosfer (KOMBAT) tahun 2019. Hasil dari 
pengujian aspek usability pada Sistem Monitoring Muatan Balon Atmosfer dapat ditunjukkan pada Tabel 3.

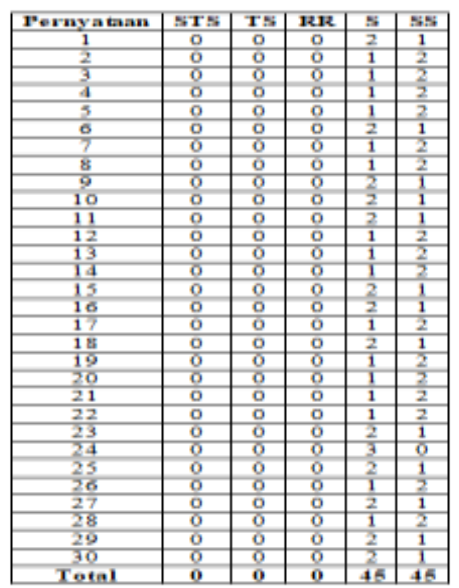

Tabel 4. Hasil Perhitungan Usability

\begin{tabular}{|c|c|c|c|}
\hline Jawaban & Jumlah & Skor & $\begin{array}{c}\text { Jumlah X } \\
\text { Skor }\end{array}$ \\
\hline STS & 0 & 1 & 0 \\
\hline TS & 0 & 2 & 0 \\
\hline RR & 0 & 3 & 0 \\
\hline STS & 45 & 4 & 180 \\
\hline SS & 45 & 5 & 225 \\
\hline \multicolumn{4}{|c|}{ Total } \\
\hline
\end{tabular}

Skor Total

$=$ Nilai total yang

didapat dari jawaban responden

$\quad=405$
$\begin{aligned} \text { Skor Maksimal } & =\end{aligned} \begin{aligned} & \text { Jumlah } \\ & \text { pernyataan x jumlah responden x } 5 \\ & =30 \times 3 \times 5=450\end{aligned}$

Berdasarkan hasil perhitungan di atas, maka hasil pengujian aspek usability terletak pada daerah Sangat Baik. Hal ini dapat dilihat pada tabel kriteria interprestasi skor.

Dari pengujian usability yang telah dilakukan dengan menggunakan kuesioner USE Quistionnaire dari Arnold M.Lund mendapatkan hasil presentase pencapaian yaitu $90 \%$. Persentase tersebut apabila dikonversi ke dalam skala kualitatif masuk dalam kategori Sangat Baik. Maka dapat disimpulkan bahwa sistem monitoring muatan balon atmosfer sudah memenuhi aspek usability dari standar kualitas perangkat lunak ISO 9126.

\section{PENUTUP}

Simpulan

Berdasarkan hasil implementasi dan pengujian perancangan sistem monitoring muatan balon atmosfer, maka dapat diambil kesimpulan yaitu sebagai berikut: (1) Sistem monitoring muatan balon atmosfer yang telah di rancang mampu mendeteksi suhu, kelembapan, tekanan udara, ketinggian dalam bentuk grafik dan juga letak lokasi dari koordinat lintang dan bujur, (2) Pengiriman data yang baik menggunakan antena bawaan dari 3DR Radio Telemetry jenis omnidirectional ini, yaitu dengan jarak antara $1-5 \mathrm{~km}$. Jika melebihi jarak tersebut maka pengiriman data rentan mengalami losses bahkan bisa juga data tidak bisa diterima oleh receiver, (3) Pengujian tingkat kualitas sistem monitoring muatan balon atmosfer ini dilakukan dengan menggunakan standar ISO 9126 pada aspek usability. Persentase yang diperoleh yaitu mencapai $90 \%$ yang termasuk dalam kategori Sangat Baik berdasarkan dari tabel kriteria interprestasi skor.

\section{Saran}

Adapun saran yang dapat disampaikan penulis pada skripsi ini yaitu karena telemetry ini hanya dapat menjangkau jarak antara 1-5 km, maka dapat dimaksimalkan dalam perancangan antena trackerjenis directional, agar pengiriman data melalui transmitter dapat dijangkau lebih jauh dan bisa diterima oleh receiver yang terhubung dengan sistem monitoring muatan balon atmosfer. 
DAFTAR PUSTAKA

Ardupilot.org. $2019 . \quad$ Telemetry. http://ardupilot.org/copter/docs/co mmon-telemetry-landingpage.html. Diakses pada tanggal 9 Agustus 2019.

Bosch Sensortec GmbH. 2019. BME280

Datasheet.https://www.boschsensortec.com/bst/products/all_pro ducts/bme280. Diakses pada tanggal 6 September 2019.

Kamsyakawuni, A. 2010. Pemrograman Terstruktur Menggunakan Matlab. Jember: Fakultas MIPA Universitas Jember.

Mercy Corps. 2005. Design, Monitoring and Evaluation Guidebook. 19 Desember 2012.URL:http://www.mercycorps. org/sites/default/files/file11571500 18 .pdf

Microsoft. 2019. Visual Studio IDE. http://docs.microsoft.com/enus/visualstudio/get-started/visualstudio-ide? view=vs-2019. Diakses pada tanggal 3 September 2019.

Permadi, Koko Himawan. 2013. Rancang Bangun Perangkat Lunak Attitude Monitoring Payload Menggunakan Sensor Accelerometer.

Pressman, R.S. 2015. Rekayasa Perangkat Lunak: Pendekatan Praktisi Buku I. Yogyakarta: Andi.

Sauro, J. 2010. Average Task Time in Usability Tests: What to Report?.https://measuringu.com/av erage-times/ (diakses pada 19 Juli 2019).

Singhera, Zafar., Horowitz, Ellis., dan Shah, Abad. A Graphical User Interface (GUI) Testing Methodology. Chapter: 7.24, 1-3, 2009.

Sudaryono, Guirtno, Suryo \& Raharja, Untung. 2015. Teory and Aplication of IT Research. Yogyakarta: Andi.

Sugiyono. 2015. Metode Penelitian Kuantitatif, Kualitatif dan $R \& D$. Bandung: Alfabeta.
Sutabri, T. 2012. Analisis Sistem Informasi. Yogyakarta: Andi. Syahwil, Muhammad. 2013. Panduan Mudah Simulasi dan Praktek Mikrokontroller Arduino. Yogyakarta: ANDI.

Wikipedia. 2019. Balon Atmosfer. https://en.m.wikipedia.org/wiki/Hi gh-altitude ballon. Diakses pada tanggal 11 Agustus 2019. 